\title{
The Refugee Woman and her Family
}

\author{
by Eva Allmen
}

As survivors of a disaster, refugee families arrive already under the stress produced by the refugee experience. Upon arrival they have to continue to cope with these stresses, as well as the new stresses that are part of the immigrant experience.

In order to help, we need to know more about the dynamics of the refugee family and the ways support can be given in restoring its members' sense of well-being to a reasonable level of functioning.

The refugee family has to deal with many losses:

- loss of the support of the extended family;

- the sense of loss of dignity and self, particularly in the case of victims of torture and imprisonment;

- loss of material possessions;

- loss of status; and,

- loss of culture and language.

To cope with these losses there is a need after escape to reorganize and reconstitute. It is essential for the survival of the family after a crisis to readjust the roles of its members to the new situation.

A critical factor of stress for refugees is not only the dislocation they experience, but also that the time between dislocation and settlement can take anywhere from six months to many years.

In some cases, the rebuilding and restructuring of family life needs to start three or four times before the final destination is reached. Some of the symptoms of stress become entrenched and others are suppressed. Since the functional necessities of life -- shelter, food and the need to secure a final destination -- are overwhelming, the psychological effects of the stress are often dclayed.

In studies of families that are victims of a disaster, the capacity of the family to rally around, to reorganize its internal resources is a key element in its members emotional and economic recovery.

Coping mechanisms often include the following:

- In some cases, families go to the extreme of isolating themselves from the outside world until it is safe to connect again.

- There may be intense activities involving all family members with a great deal of interaction and time spent together. - They may develop ways that would supplement the loss of the extended family, such as establishing networks with fellow refugees which provide a semblance of the extended family.

\section{Roles of Women}

Women's pivotal role in family life is a known fact, but this role is even more critical in the refugee situation. A great deal of the rebuilding, reorganizing and nurturing of the family falls on women. They are called upon to continue their task of maintaining a home during transition and immediately upon arrival. Regardless of the circumstances, they must cook, take care of the children and be supportive to others.

Women in these situations have to expand their traditional roles. They must maintain their status as homemakers and mothers and must assume additional roles as workers or students. At the same time, men's role as providers may be undermined in the context of a new country, forcing them to assume tasks that were previously considered female functions. Very often the extension of the woman's role is resented as it is seen as a threat to the family.

\section{Helping Strategies}

At Ontario Welcome House, hundreds of refugee women come for services. This is but one of the agencies that services refugees in Toronto, and is the one with which I am most familiar.

Through many years of observation, I have formulated the following suggestions to facilitate and improve the services rendered to refugees:

1) It is important to recognize that most refugees are successful and capable individuals. They are only recent casualties of political and social events well beyond their control.

2) Service provided should investigate and note their previous life style and not make assumptions based on what they do or where they live now.

3) Child care requires sensitive support. The economic need that leads to a parent's decision to place a child in the care of strangers is difficult to cope with.

4) Refugee women are often extremely isolated. They feel the loss of the extended family's support. Alternative networks of women with similar experiences would help.

5) Because of the stresses and the length of the transition from exile to settlement, refugee women's health may have been neglected. They need extensive health care and nutritional information.

๑) Refugee women need language and job training if they are to effectively contribute to the economic betterment of the family.

7) The trauma and the losses of exile often cause emotional problems. Moreover, a new life in a new land carries with it additional pressures and burdens.

Eva Allmen, a Supervisor of Settlema. Services on leave from Ontario Welca. House, is currently involved in tablishing a National Working Group Refugee Women under the sponsorshif the Canadian Council for Refugees. 


\section{Women and Religion: "Mennonite Hmong"}

\author{
by Daphne Abergel
}

The Hmong of Laos, a traditionally animist and preliterate people, speak a Sino-Tibetan language and are culturally close to the Chinese. Due to their strategic location and scouting and fighting skills, the Hmong were singled out during the war in Indochina to collaborate with the CIA as front line guerrillas. The eventual assumption of power in 1975 in Laos of communistbacked Pathet Lao forces, resulted in increasing hardships and danger for those Hmong who had complied with the U.S. Army Special Forces. By 1980, more than $110,000 \mathrm{Hmong}$ were forced to flee Thailand. Most Hmong from Thai refugee camps resettled in the U.S., France, Australia and Canada. The Mennonite Central Committee's (MCC) policy to aid sponsor cases like the preliterate and nonindustrial Hmong resulted in a proportionately high influx of Hmong to Ontario; hence Kitchener-Waterloo (K-W) has been dubbed the "Hmong Capital" of Canada by immigration officials.

Of the fifteen to twenty Hmong families that initially resettled in KitchenerWaterloo in 1979 , only five or six were baptized Christians before their arrival. Over the last seven years in Canada there has been a steady increase in the numbers of Hmong converting to Christianity, specifically the Mennonite faith. The Hmong Christian Church (Mennonite), established under the auspices of the Mennonite Conference of Ontario and Québec in 1984, has proven to be an important arena for the negotiation of Hmong beliefs, values and norms, specifically those relating to male-female relationships.

Of the estimated sixty-five Hmong families now living in the Waterloo region, approximately one half attend the Hmong Christian Church, a substantial increase from six years ago. The Hmong church has adopted an "open door" policy for those Hmong who are intimidated by rigid institutional rules or structures. Among older Hmong in particular, the church serves more as a facility for social interaction with other Hmong than as a source of spiritual help. The church leadership has struggled over the last few years to get people involved. Recently Hmong women began to be very active in the church. Although the young Hmong pastor tried to draw women into the church by offering Hmong literacy classes to women and organizing workshops on nutrition and hygiene, the women themselves have taken the initiative by contributing their services to the congregation.

When Hmong women first arrived, they were unresponsive to volunteer efforts. They were also reluctant to get involved in government and community-sponsored language and job-placement programmes. When asked why they resisted attempts to resettle and integrate them into their new community, they responded that they felt uncomfortable participating in these programmes with Hmong men. Hmong women were in these and other cases abiding by traditional norms governing male/female roles. For example, the traditional custom of arranged marriages between young teenagers continued until Mennonite church officials intervened and counselled Hmong on acceptable Christian and Canadian legal practices concerning marriage.

The involvement of women in the workforce has brought about significant changes to the traditional notion of the family as an economic unit, particularly in those cases in which women are the sole source of family income. Virtually all Hmong women are wage earners working on assembly lines in local factories. Women now exercise greater freedom in choosing marriage partners and are marrying later.

Although these changes to some extent parallel those of the much larger Hmong communities in the U.S., there are major differences between Canadian Hmong and their American counterparts. In American cities such as Denver, Minneapolis and Orange County, segmentary kinship based on corporate sub-lineages at the clan and lineage levels is common. Relationships based on common descent link many Hmong families within the wider Hmong clan-based system in the U.S, providing them with a wide range of networks and support structures. By contrast, $\mathrm{K}-\mathrm{W}$ Hmong are a small and highly differentiated community consisting of people from all parts of Laos, most of whom are not related to others in the area. Thus what one finds in K-W is a relatively small community of Hmong, internally differentiated along geographical, ethnic, linguistic, religious and other lines. It is clear then that a significant number of Hmong attend church out of a desire for community and not doctrine. The Hmong Christian Church thus provides an opportunity for regular social interaction which would otherwise be severely curtailed. However, the church proviaes additional incentives for women in particular. The Women's Fellowship Committee is available as a forum in which women can share their ideas and concerns. Church attendance not only gives women the chance to socialize but also share information and make use of educational facilities and other services offered by the church. Most importantly, it provides an opportunity to build important support networks.

Although it may be a while before these women gain the confidence to face new challenges, the congregation will continue to provide them with a non-threatening environment in which they can continue to negotiate their identities as Hmong women in Canadian society.

Daphne Abergel is a doctoral candidate in Sociology at York University working on"Mennonites" in Kitchener-Waterloo.

\section{A Note on Lowland Lao Women}

In Toronto, Lao women actively suppor the establishment of a Lae Buddhis: Temple. Refugee groups such as the $L$ so have lost their own religious institutions at the very time they fice the most severe personal stress and alienation. Allhough women cannot be ordained as monks, they actively participate in ritual events and provide both financial and food resources to the temple. Women outnumber men at services, and it is women's donations of food and money that make it possible for the Lao to maintain their ritual traditions in Toronto. 


\title{
New Experiences for Refugee Women
}

\author{
by Joy Simmonds
}

Latin American refugee women new to Toronto, have tremendous obstacles to overcome in settling here. Disorientation, uncmployment and an inability to communicate in English, prevent them from integrating into their new society. Over the past four years New Experiences for Refugee Women (N.E.W.) has developed a unique programme that addresses these and other problems.

The goal of the programme is to assist refugee women with their social, cultural and economic integration into Canadian society. To achieve this we focus on each woman as a whole person with many varied and interrelated abilities, experiences and needs. We see her as a woman first, as a refugee, a mother, a wife, a social bcing, a worker. Our three-component programme of English, Orientation and Employment has been designed to build on all of these.

\section{Who Are the Refugee Women at N.E.W.?}

The refugee women at N.E.W. come primarily from Central America, mainly from El Salvador and Guatemala. These women have been forced to leave their countries due to the escalation of civil war. They have seen and experienced violent repression in the form of killings and disappearances of family members and in some cases have themselves been in prison and tortured. They have been forced to leave their homelands and make the long and arduous journey to Canada.
Many have been fortunate enough to have been sponsored by the Canadian government and so have come here directly. Others have had to go via the illegal and dangerous route through Mexico, crossing into the U.S., and slowly proceeding north to Canada. Some of our participants have taken years to get here and have lost family and friends along the way to illness, death and deportation. While still dealing with the emotional, psychological and physical trauma of the past, these refugee women arrive in Toronto and are bombarded by the demands of a new society. Most are mothers and wives and have the awesome responsibility of holding their families together. Marital and family problems often include abuse and violence. Many have limited work experience and those who have skills find that they are not recognized in, or transferable to the Canadian labour market. Financial crisis is common. Affordable housing is practically non-existent. The women often have less access to English classes than their husbands and children and so become isolated from Canadian society. The loss of community and familiar surroundings, coupled with an inability to fend for themselves leads to a loss of identity and self-worth.

\section{N.E.W. Programme}

N.E.W.'s programme is six months long and is offered to refugee women in groups of fifteen.

\begin{tabular}{|c|c|}
\hline \multicolumn{2}{|c|}{$\begin{array}{l}\text { Reasons for Coming to Canada } \\
\text { The following results are from research conduced by N.E.W. in July 1986. The total } \\
\text { number of people surveyed was seventy-five. The figures represent percentages. }\end{array}$} \\
\hline Lives of family members in danger & 54.6 \\
\hline No longer wanted to live in a state of war & 52.0 \\
\hline Life in danger & 49.3 \\
\hline $\begin{array}{l}\text { Family members of friends: } \\
\text { imprisoned }\end{array}$ & 41.3 \\
\hline tortured & 37.3 \\
\hline killed & 22.6 \\
\hline To join relatives & 9.3 \\
\hline To join husband & 8.0 \\
\hline Other reasons & 13.3 \\
\hline
\end{tabular}

The first fourteen weeks of the programme take place on the premises of N.E.W., and involve classroom training, including:

- English as a Second Language (ESL).

- Orientation/Information/Life Skills.

- Employment Preparation.

The final twelve weeks consist of on-thejob training and Canadian work experience. During the six months, each participant receives a training salary and a metropass.

\section{English as a Second Language}

Intensive ESL instruction is provided to prepare participants to communicate effectively in day to day situations. Emphasis is on participants speaking English and role playing. Activities include field trips into the community, audio visual materials, and music. The programme is staffed by bilingual instructors and volunteers.

\section{Orientation, Information and Life Skills}

This component specifically addresses the sense of alienation and the loss of identif and confidence experienced by Lat American refugee women in the process? settlement.

Through orientation/information ses, participants begin to understand historical, political and economic $c$ ? within which immigrants and have come to Canada. They familiar with the basic infrastructu community and learn how to ac. utilize the resources. Finally th. to know legal rights and respoe as a woman, a refugee, a par tenant.

The life skills sessions include.

- Assessing personal situation American woman in Canada. 

- Identifying personal needs and
aspirations

- Developing communications and assertive skills

- Setting goals and making decisions.

Personal counselling is provided throughout this process.

\section{Employment Component}

The Employment Preparation provides participants with an opportunity to assess past work experience, skills, education, and English levels.

Sessions prepare women to do job search, to conduct themselves in a job interview, to fill out application forms and employment contracts. Information is also provided on employment standards, labour legislation, employee rights and benefits and pay cheque deductions. They learn of possible entry-level employment opportunities and of their qualification requirements.

The work placement involves on-the-job training in an organization. Work placements are secured with the understanding that the participant will work and receive training for four months and will then be hired as a permanent employee.

The employment component has always faced somewhat of a dilemma. The reality. of today's employment market, is that most of the entry level jobs currently available to participants in N.E.W.'s programme are found at the lower ends of traditional female occupations such as clerical work, community work, day care, home service and light manufacturing assembly work. Past experience has been that Latin American refugee women are primarily interested in jobs they can relate to and that have good working conditions and reasonable wages. It is inevitable that the majority of participants will find employment in traditional women's occupations.

Joy Simmonds is the Community Liaison worker at N.E.W.

\title{
Service Delivery to Southeast Asian Refugee Women
}

\author{
by John Van Esterik
}

The delivery of services to refugees in three counties of upstate New York occupied much of my time and attention for almost four years in the early 1980s. As an anthropologist who managed a programme of educational and employment services to refugees, I was interested in applying an anthropological analysis to the delivery of such services.

The refugee population in the three rural counties of upstate New York covered at the time was mainly Southeast Asian. Almost half of the adult population had little or no education, the bulk of these being women.

Women are responsible for household operations in all Southeast Asian groups. Thus, women were particularly affected by the limitations attendant upon large family size and low incomes. Southeast Asian women play important roles in the household, participating in all family decisions and usually handling the family budget and income.

Yet, refugee women are especially disadvantaged in North American society since the majority of the women have much less education than local populations or refugee men. The women are responsible for the care of children in a society where child care is expensive and difficult to obtain. In their own societies, child care was often left to elderly relatives, friends, or neighbours, all of whom lived close by.

The programme of services sought to provide educational and employment placement services to all refugee adults in the three-county area. But it was soon discovered that refugee women faced problems that impeded the delivery of programme services to them.

\section{Education Backgrounds}

Many Southeast Asian refugee women were very poorly educated and therefore unprepared for living in the modern, postindustrial society they were entering. Rural Southeast Asians often prefer to have males formally educated than women. Yet, refugee women wanted and expected to work and earn money. It became very apparent that a one entry-level salary family could not afford many consumer goods in the new society they had entered. Refugee women seeking employment had to face the problem of limited educational backgrounds and their continuing responsibilities of homemaking.

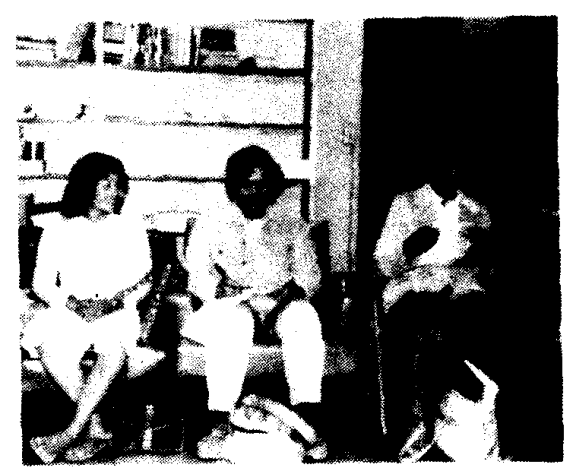

A few students in the Beginning Class, St. Paul's Methodist Church, Ithaca, New York.

\section{Day-Care Services}

The English as Second Language (ESL) classes were held in space provided by two churches in the largest urban centre (population: 27,000) in the counties. A problem that arose immediately was daycare services. No provision was made for day. care. 
The programme sought to solve the problem by planning class times so refugee women could trade off babysitting chores. Elderly relatives suffering their own disorientations in a new land were not prepared to care for two or three young children. Besides, refugees did not live all logether and were not necessarily neighbours or, for that matter, friends. As a result, some private sponsors paid for professional day care. A classroom space with a day-care facility was donated, and two day-care workers were hired. However, none of these "solutions" was satisfactory.

\section{Travel}

Another problem was getting children to the day-care centre, since New York law required infant seats for any young child travelling in a car. Some refugees did not have cars and walking with three or four children through winter snows was not very convenient. This was usually solved by breaking the law and carrying several children in a car owned by one of the refugees.

\section{Child Care in the Home}

In Southeast Asian villages, seven, eight, and nine-year-old daughters often take care of younger siblings. Of course, this is done in a context of open dwellings in proximity with the houses of relatives and well known neighbours. In housing projects even in small towns people are not always very friendly or understanding. In one case where both refugee parents worked, a number of complaints was raised against their leaving young children alone at home. At one point the state child abuse agency was called in by a neighbour. State workers seemed receptive to cultural explanations but ulimately the law was obeyed.

\section{Training Courses}

Education involved more than English language training. Some special courses were devised to directly appeal to women's interests and concems. One of the most successful was a sewing class utilizing resources of the local vocational high school. Using patterns and power sewing machines appealed to many refugee women who in their home country weaved cloth and made their family clothing.

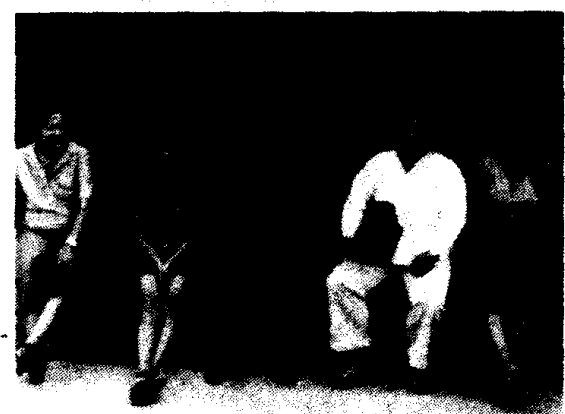

Some refugee women waiting for their sewing class to begin.

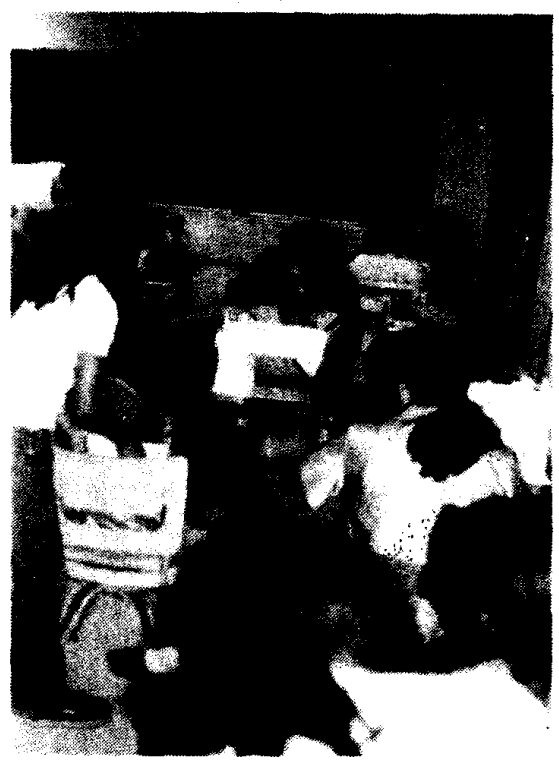

Refugee women attending a popular sewing course. This course had to be dropped afterwards because it could not be readily justified for employment purposes.

Unfortunately, it was difficult to justify the course for employment purposes. A cottage industry in sewing could not be supported because it was against the law to do piecework in the home. This course, however popular and well attended, was therefore dropped. Other courses such as housekeeping, food preparation, and health services, which had specific employment goals, were not as popular, but offered better opportunities for jobs in local restaurants, cleaning jobs, and other service occupations.

\section{On-the-Job Training}

With their poor eduational background, many refugee women had difficulty leaming to read and write. It was soon discovered that even seemingly simple, labour-intensive jobs like cleaning required knowledge that many Southeast Asian refugee women did not have. Cleaning motel rooms, fraternity houses, and private homes demanded a knowledge about a wide range of products, techniques, and equipment these women had no experience with. The programme had to provide on-the-spot tutors and interpreters to lead the refugee woman through the job. Otherwise, even this minimum wage employment could be lost to the family.

\section{Summary}

In summary, the programme sought to address refugee women's needs. But there are barriers for women to access these services. These constraints include government and legal restrictions that limited the development of cottage industries, traditional child care and access to day care. The cultural characteristics of refugee women, including their lack of literacy, education and job readiness, posed additional difficulties.

John Van Esterik teaches in the Soc Science Division and co-ordinates the $T$. Studies Project at York University. 


\section{Salvadorean Refugee Women and Employment Creation Programmes in Costa Rica}

\author{
by Tanya Basok
}

As decades of political represssion had by 1980 culminated in a full-scale civil war in $\mathrm{El}$ Salvador, thousands of its victims fled the country in search of haven. Costa Rica was viewed as one of the most politically stable and non-repressive countries of Central America and therefore many Salvadoreans asked this country for asylum. At the end of 1980 , there were more than 2,000 refugees in Costa Rica and by March 1981, the figure had risen to over four thousand. Between 1980 and 1983 an average of 9,000 refugees per year arrived in Costa Rica.

As early as the end of 1980, the Costa Rican government realized that the alarming flow of refugees was not going to stop and that new measures had to be adopted to attempt to integrate refugees into the economic structure of the country. In order to protect national labour, it was decided not to allow refugees to compete for wage labour jobs. Instead, a program designed to create small and mediumsize urban and agricultural businesses for refugees was introduced. The Costa Rican Red Cross was put in charge of programme implementation. The funds for this programme were to come from the United Nations High Commissioner for Refugees (UNHCR). Later on, a number of other voluntary and government agencies assumed the responsibility for refugee resettlement and started implementing refugee projects.

More than half of the implemented projects for refugees have failed. In 1986, during seven months of research, the author was able to locate and interview members of sixty-seven small urban projects for Salvadorean refugees. When the average income earned by women in projects is compared to that of men, some significant differences are noted. While men earned on average 7,284 colones per month, women were eaming only 5,438 ( $1 \mathrm{Can} \$=27$ colones in 1982, 40 in 1986). How can this be explained?

The answer can be found in the difference between two employment creation programmes and the sex distribution within them. At the end of 1980, the Costa Rican govermment, in cooperation with the UNHCR, adopted a "durable solution" model of refugee resettlement. Under this programme, small and medium-size businesses of a predominantly collective nature were established. Apart from contributions for machinery, tools, furniture, etc., agencies used to pay the salary and rent for the first few months until a project reached self-sufficiency. Refinancing and technical expertise were offered along with some short training and business administration courses. The initial investment per capita was 63,723 colones. When refinancing is taken into account, the total investment per capita becomes 73,208 colones. At the same time, more than half of these projects failed. Those businesses which survived, lost about half of their members. Therefore, it was decided that the programme was very cost inefficient and had to be replaced.

The new programme to replace the "durable solution" projects was called "local settlement" and was to be administered by a govemment agency funded by the UNHCR. Under this programme, some refugees received small domestic sewing machines and ovens as well as raw materials, some received tools and raw materials and others just raw materials. The average investment per beneficiary was 13,855 colones. No assistance with initial salary or rent was provided; nor were technical assistance or refinancing schemes made available. The beneficiaries of the "local settlement" programme were expected to work at home.

Sex distribution of the projects for Salvadorean refugees is the following: there are thirty-seven projects which include only men, twenty-three which include only women and seven which are mixed. Out of the thirty-seven projects for men, twenty-three are "durable solution" projects and fourteen are "local settlement" ones. For women's projects, the reverse is true. The majority (sixteen out of twentythree) of the projects are "local settlement" ones and only seven businesses were established through the "durable solution" programme. All seven "mixed" projects were implemented through the "durable solution" programme.

Few women joined the "durable solution" projects because most of these projects were of a collective nature. Project members were expected to rent a place where all of them could work together. Women who had small children could not accept this arrangement Day-care facilities were scance in Costa Rica and, when availible, it was so expensive that a woman's salary generated in a project at times was not sufficient to pay for it. For this reason, many women with small children preferred staying at home while receiving the UNHCR emergency aid.
In 1985, the UNHCR assistance was discontinued for Salvadorean refugees in Costa Rica and, as a consequence, all refugees who were still receiving aid were expected to integrate themselves into the labour force. The "local settlement" programme enabled women to engage in some productive activity while taking care of their children.

Most of the women in the programme were given a sewing machine or a stove. Some major problems arose. First, it was assumed that all women could sew or bake. However, it turned out that their domestic skills were not sufficient to make their businesses work well. Second, the machinery was inadequate. The average investment in machinery per "durable solution" project was 38,650 colones, while in the "local settlement" programme it was only 11,300 colones. The sewing machines and stoves given to Salvadorean women were suitable for poor quality domestic production, which made it difficult for the beneficiaries to compete in the market.

Third, when "durable solution" projects were implemented, the first few months of rent were paid for them. That gave participants an opportunity to find a location in a relatively good neighbourhood. When the assistance was cut off, they had already had a chance to establish a clientele and could then continue paying the rent on their own. The "local settlement" recipients, on the other hand, who had mainly survived on the UNHCR assistance and some occasional jobs, lived in low-income houses in poor neighbourhoods. The "local settlement" programme did not offer them any opportunity to move out of their neighbourhoods as no assistance with rent was offered. Although these small producers saw their location as an impediment to the survival of their business, they nevertheless did not want to take the risk of moving out of an inexpensive house. Their clients therefore were mainly low-income people who did not generate a sufficient demand for custom-made goods and paid little on credit.

While all this may not create a problem for refugee women whose husbands also earm an income, the situation of single mothers is truly desperate, as they cannot support their families on what they eam from the "local settlement" programme. It is these women who need more instimitional support

Tanya Bosok, a doctoral candidate in Sociology affiliated with the Refugee Documentation Project at York University, has recently returned from field-work research on the resettlement of Salvadorean refugees in Costa Rica. 